\title{
The Post-Pastoral Elements in Michael Longley's Poetics
}

\author{
Cassandra O'Loughlin \\ University of Newcastle, Australia
}

Copyright (c) 2018 by Cassandra O'Loughlin. This text may be archived and redistributed both in electronic form and in hard copy, provided that the author and journal are properly cited and no fee is charged for access.

\begin{abstract}
When discussing the internal contradictions and issues of ideology and representation posed by the literary pastoral, Lawrence Buell suggests the need for "a more mature environmental aesthetics" than the pastoral provides (32). Terry Gifford insists that "“A mature environmental aesthetics' would need to recognise that some literature has gone beyond the closed circuit of pastoral and anti-pastoral to achieve a vision of an integrated natural world that includes the human" (148). The Irish poet Michael Longley has increasingly avoided pastoral's anthropocentric worldview that the universe centres on humans; he reassigns preference to the concerns of the biosphere, including its human participants. He seamlessly integrates social systems and ecosystems, proposing what Donna Potts terms a "more radical reordering of cultural values" (79). This article analyses the ecocritical value of Longley's poetry in light of Terry Gifford's suggested requisites for postpastoral literature.
\end{abstract}

Key Words. Michael Longley, Terry Gifford, post-pastoral poetry, ecopoetry, ecocentrism, ecocriticism.

Resumen. A la hora de discutir las contradicciones internas, así como otros temas relacionados con la ideología y la representación en el terreno de la literatura pastoral, Lawrence Buell sugiere que es necesaria "una estética medioambiental más madura" de lo que proporciona el género pastoral (32). Terry Gifford, al respecto, señala que "Una estética medioambiental madura precisaría reconocer que cierta literatura ha salido del circuito cerrado de lo pastoral y lo antipastoral para alcanzar una visión integradora del mundo natural abarcando lo humano" (148). El poeta irlandés Michael Longley ha evolucionado gradualmente hacia un abandono de la visión del mundo antropocéntrica de lo pastoral según la cual el universo se centra en los seres humanos; por el contrario, dirige sus preferencias hacia temas relacionados con la biosfera, incluyendo a los humanos que participan en ella. Su poesía integra sin ningún tipo de fisuras tanto sistemas sociales como ecosistemas, materializando lo que Donna Potts define como "un reordenamiento más radical de los valores culturales" (79). En este artículo se analiza el valor ecocrítico de la poesía de Michael Longley a raíz de los principios que Terry Gifford sugiere para una nueva literatura pospastoral. 
Palabras clave. Michael Longley, Terry Gifford, poesía pospastoral, ecopoesía, ecocentrismo, ecocrítica.

In an interview given in 2003, when asked if his meticulous descriptions of the natural world are counters to the "long shadows of history" that are his context as a poet, Michael Longley replied: "The most urgent political problems are ecological: how we share the planet with the plants and the other animals. My nature writing is my most political. ... Describing the world in a meticulous way is a consecration and a stay against damaging dogmatism" (Randolph 305). He is conscious of the need to take responsibility for ecological relationships and the ultimate survival of all species, and he finds ways of approaching and incorporating the broader political issues into that framework in his poetry.

The aim of this article is to follow three main themes implicit in Longley's reply to Randolph. The first is his concern with the larger question of preserving the integrity, stability and aesthetics of the biosphere. Second, is his development of a literary means to express synthesis and symbiotic relations to support the ideas of embeddedness as a personal response to human participation and interaction with the non-human world. The third is his poetic response to the impact of Ireland's social and political turmoil on all lifeforms. In particular I will look at ways that "Longley's aesthetic fidelity to the imagination is inextricably tied to his ethical interest in effecting harmony between opposing cultures in Northern Ireland" as pointed out by Richard Rankin Russell in Poetry and Peace (92).

Given the cultural background of the Irish "Troubles", engraving a place for poetry involves engaging with major social and ethical issues. This is problematic primarily because the social issues are complex and multifaceted, and representation through the creative arts is essentially "made up" - both are contingent upon perspective and motive. Elmer KennedyAndrews notices that "Longley's idea of interconnectedness includes the inseparability of the aesthetic and the ethical" within the cultural context as well as the ecological one (76), a point that is particularly relevant to this article.

Ethics in Longley's work takes an ecocentric rather than an egocentric direction. As Laurence Coupe points out, the appeal to ecological concerns is primarily a matter of ethics (4). By insisting that the non-human world matters, Longley challenges the notion that other species are subordinate to the human given the human capacity for assigning meaning. In his work there is also lack of presumptuousness in which the other - it may appear banal happenings are given a more charitable appreciation than the historical. The moral principle he adheres to in his aesthetics ensures recognition for those parts of the natural world that are sometimes not noticed or ignored, or used for utilitarian purposes. His poetry ultimately speaks in defence of nature.

This article analyses the post-pastoral elements in Longley's poetry in light of recent developments in ecocritical theory, especially with reference to suggestions put forward by Terry Gifford to identify post-pastoral literature. Ecocritical theorists such as Lawrence Buell and Terry Gifford recognise the importance of literary pastoralism as a cultural force into the future, but they suggest change in its value structure is needed to redirect human consciousness in relation to a threatened natural world. Buell suggests the need for a more "mature environmental aesthetics" than the pastoral provides (32). Gifford insists that "“mature environmental aesthetics' would need to recognise that some literature has gone beyond the closed circuit of pastoral and anti-pastoral to achieve a vision of an integrated natural world that includes the human" (148). In the last chapter of Pastoral Gifford argues for a continuation of the literary pastoral but one that seeks to avoid "the traps of idealisation [a common trait in the traditional pastoral] in seeking to find a discourse that can both 
celebrate and take some responsibility for nature without false consciousness" (148). This attitude reflects the change in contemporary pastoral ideology within the development of ecocriticism as described by Buell: "As this ecocentric repossession of pastoral has gathered force, its center of energy has begun to shift from representation of nature as a theater for human events to representation in the sense of advocacy of nature as a presence for its own sake"(52). Longley moves away from traditional English and Irish pastoral modes to a more realistic representation of experience, as does his contemporary Seamus Heaney whose poetry will be used in this article for comparison.

The work of both of these poets is self-consciously pastoral in their depiction of the tension between oppositional states, traditionally between urban and rural worlds. Each in their own way presents the quotidian realities of rural community life to transcend the pressing socio-political circumstance. Longley discerns the exquisite intricacies of birds, bird's nests, insects, flowers, and the vestiges of humans and others in the environment, particularly in the earth, sky and waterways around the townland of Carrigskeewaun in County Mayo, Ireland. As explained by Donna Potts, Heaney's poetry is "the product of English pastoral" and "of early Irish nature poetry that is culturally inherited from the indigenous Irish" (49). In Preoccupations, Heaney suggests that the Irish "landscape was sacramental, instinct with signs, implying a system of reality beyond the visible realities" (132). Implicit in his assessment of the role of poetry is the need to restore this system of reality. Longley, on the other hand, highlights the cultural value of a realistic pastoral "retreat" while also awaking awareness of environmental threats, a serious case against pastoral in that pastoral does not envisage the threat of environmental catastrophe. What displaces the familiar traditional pastoral sentiments here is the threat to all species by changed global conditions. Longley acknowledges, in light of new scientific data concerning the threat to the survival of our species and others, the precariousness of our situation.

Following Longley's sabbatical after the release of Poems 1963-1983, the appearance of Gorse Fires marks the beginning of a period that is of particular interest for this article's concern with post-pastoral. As suggested by Alan Peacock, this period “condensed Longley's ability to image the macrocosm in the microcosm, to elide distinctions between the human and the natural world and to conflate personal and larger histories" (ix). The points mentioned by Peacock are central to this article as post-pastoral qualifiers. They support Longley's outlook concerning the social, political and cultural imperatives of his time and in particular his concern for the interests of ecosystems and its human members in a post-pastoral sense.

\section{Towards an Ecocentric Perspective}

The literary pastoral first took form in the idylls of the Greek writer Theocritus and in Arcadian nostalgia for a past Golden Age in the Eclogues of the Roman writer Virgil. In chapter four of What is Pastoral? Paul Alpers argues that Virgil's transformation of Theocitean bucolic established pastoral as a literary form (137-138). Elsewhere he suggests that there are no clear definitions as to what works count as pastoral or "whether pastoral is a historically delimited or permanent literary type" (Alpers 8). The general consensus is that its fundamental motive is resentment of urban life, and its characteristics are: idyllic countryside, countryside as a setting for song, an atmosphere of ease or idleness, a conscious attention to Art and Nature, shepherds as singers, and self-consciousness about these matters (Alpers 22). It is evident that all its features belong to fiction in that rural life is, in reality, hard work and often involves less than idyllic living and working conditions.

Pastoral conventions have continued to develop, modify and multiply to the present day. From a contemporary perspective, the main identifiers of pastoral of interest for this article are its propensity to anthropocentrism and romantic or nostalgic sentiments: in the 
traditional pastoral, the natural world is considered to be available primarily for sentimental, utilitarian or instrumental purposes, rather than for its own intrinsic value. Its focus is on human tendencies of control and idealism. We must admit that given our awareness of contemporary problems concerning the natural environment, as well as western philosophies and posturing in this age of "environmentalism", ecocritical theorists need to redefine pastoral in relation to literature's representation of nature. As conceded by Buell, "pastoralism interposes some major stumbling blocks in the way of developing a mature environmental aesthetics" (32).

The redefinition of literary representation of nature would necessarily involve a better appreciation and depiction of the material realities and complexities of nature, and more intense questioning of human values. The world is a dynamic matrix of lifeforms that operate independently, outside of human control, a fundamentally humbling reality. We realise that the natural world is remarkably enduring and robust; we can expect all lifeforms to behave in certain ways as we accept as a given their makeup and integrity. As expressed by Joseph W. Meeker:

Ethologists have consistently discovered that even the simplest of creatures follow exceedingly complicated and often highly sophisticated patterns of behaviour, many of which continue to defy human understanding. Animal rituals of reproduction and rearing, defense of territory, maintenance of social systems, nest-building, migrations, and food-gathering are quite as intricate as comparable human activities. (164)

It's not surprising then that Gifford's first suggested requirement for post-pastoral poetry is that of "awe in attention to the natural world" which serves to motivate the questioning of human evaluation of the other than human world (152).

In "According to Pythagoras" in The Ghost Orchid Longley's narrator says, "Think of peacocks, eagles, doves, the bird-family / as a whole, all starting inside eggs: hard to believe" (CP 202). Through to the last poem "Image" in his latest collection Angel Hill, Longley emphasises his wonderment for the encompassing world and the inspiration it is for poetry:

The last day of the year:

Greylag geese are flying

In regular formation

Along the shoreline, sky-shapes,

An image of poetry. (59)

Expressions of this kind do not derive singularly from scientific revelation or a naturalist's knowledge or an ecologist's educated observation, but from experiential awareness of inherence in all natural things. An awareness of this kind encourages the acknowledgement of self-governing forces in the natural world.

Increased experiential awareness of environmental interdependencies between species calls for the redefinition of literary pastoral in terms of new and more complex understanding of our relationship with the other-than-human. The idea of the "fundamental interconnectedness of all things" (words found in the poem "According to Pythagoras"), informs Longley's entire oeuvre and is crucial for my argument. In poems such this one, all flesh is subject to the cyclical life and death patterns of the natural world, for instance, a point expanded upon by Elisabeth Delattre ("The Great War" 79-81). The complex flux of the natural world is presented pragmatically in biological and physical terms in poems such this: "When in good time corpses go off and ooze in the heat / Creepy-crawlies breed in them". 
The "creative-destructive universe [is] equally in balance in a continuous momentum of birth and death, death and rebirth, growth and decay, ecstasy and dissolution", which is the second fundamental aspect of the post-pastoral as determined by Gifford (153). The reader realises that his/her inclusion in the cycle of the creative-destructive universe is inevitable, no matter how distasteful that appears. Longley's personae and his physical structures are embedded in the world; earth eventually takes all life forms back into itself. There is a sense of dwelling amid change and uncertainty.

Longley describes the natural world as an ever-changing course of action, rather than being in a state of stasis. In his poems about the domestic space, for instance, there is often a sense of changeability and vulnerability for both the inhabitant and the habitat, important signifiers for post-pastoral literature: there is "some sense of the environment as a process rather than as a constant or a given", one of Buell's prerequisite's for environmentally oriented work (8). In his interview with Randolph, Longley says: "The bones of the landscape make me feel in my own bones how provisional dwelling and home are" (307). The concept of home, for instance, is elusive and ethereal in his poetry. Just as is the case with living things, the imagined material home is subject to change and decay. In "Remembering Carrigskeewaun" in Gorse Fires (CP 170), for instance, "Home is a hollow between the waves, / A clump of nettles, feathery winds". In "Architecture" in The Echo Gate, the houses are make-shift and exposed to elemental ruin. The house on the seashore is subject to destructive winds. The house on the Bleach Green is a stump of a leafless tree that can be "occupied but never lived in". The house made out of turf is identified as a pyre (CP 122).

For Longley, nature does not discriminate between the human and the non-human; both are subject to dwelling in uncertainty. We are reminded that all of our efforts are entrenched in what David Abram describes as this "living dimension" of an ever-changing world (41). Gary Snyder reminds us that "the process and essence of nature, is also an ordering of impermanence" because the world is nature, and nature is inevitably "wild" and "free" (5). Longley depicts that wildness in his poetry as a kind of freedom to exist and die as nature designs. In his poem "Bird-Watching", for instance, the narrator contemplates his own passing: he wants his ashes "wind-scattered" amidst the comings and goings of tufted ducks, lapwings, swans and starlings (Angel Hill 56). In that poem he says "I wouldn't mind dying now, I think, / Shutting at last my bird-watching eyes, / A starling-whoosh in my inner ear". His time of dying is, however, dictated by nature. The momentum continues in the narrator's own sense of being part of the cycle of life and death; his existence is no more or less important than that of other species. Human vulnerability within the essentially unknowable and ever-changing natural environment lends a sense of humility to his poetry.

For Heaney, place and the natural world might mean stability during a time of upheaval and threats to personal and national identity. John Kerrigan, when referring back to Heaney's Place and Displacement notices: "the excellences and limitations of Heaney derive in no small measure from his experience of 'dislocation' in Ulster" (144). Poems such as "Gifts of Rain" (from "Wintering Out", in Opened Ground: 50-52) appear to represent for the poet a stable, long term association with place, a fixed point of reference - stability yearned for in a time of chaos. Moyola, the river, "breathing its mists/through vowels and history", is bedded in the "locale"; a "shared calling of blood" hints at links to his Irish ancestral heritage.

Despite the sense of human vulnerability in Longley's work, there is also evidence of hope and rejuvenation. In A Hundred Doors, he introduces his grandchildren, his hope not only for a bright new beginning but also a means of perpetuating his memory. He presents the expectation of recovery despite the political and ecological imperatives of his time. Nature too is depicted as possessing a remarkable capacity of perpetuity and renewal, to recover in accordance with natural laws:

I have been writing about this townland 
For fifty years, watching on their hummock

Autumn lady's tresses come and go and,

After a decade underground, return

In hundreds. ... ("Age" in Angel Hill 57)

Longley also acknowledges the right of the other-than-human to exist under their own terms, as does Heaney in poems such as "Drifting Off" (OG 275-6), for example, but in case of the latter, threat continues between the human and other species, and eventual conflict: for Heaney, the narrator's "spurs" are "at the ready" to fend off birds.

Although it is not always obvious, an anti-anthropocentric strategy informs many of Longley's poems. In "The Hut" in The Weather in Japan, for instance, time is "measured by falling water" (CP 269). This obliquely challenges the established concept of time. When discussing Thoreau's conclusion that "time is but the stream I go a-fishing in", Max Oelschlaeger, in The Idea of Wilderness, reminds us that this statement "implicitly contradicts ... the conventional idea of scientific time (Newton's absolute time, part of the structure of the universe, and fundamental to the modern worldview that sure and certain knowledge is possible)" (154-5). Time for Longley is biological. In his organic, fluid handling of time, place and identity, anthropocentric reasoning is debunked. His poetics exceed common experiences that are fixed by rational and utilitarian categories; they reveal "an active contact with the world", which allows us to envisage a reality that is "enchanted by imagination, already composed of dynamic contraries" (Bachelard 76). The world of the individual poem is presented as a coincidental and simultaneous whole, which engages with the senses as is the case with poems such as "Metamorphoses" in The Echo Gate, (CP 140) for example. See Delattre's analysis of Longley's Snow Water in relation to Bachelard's phenomenological approach when discussing poetic writing as the sensory experience of the world.

\title{
Sensory Perception and a Sense of Connectedness
}

Longley's poetics are intent on sensory experience in that he expresses feelings about self, being and earth in a connected sense; the perceiving body is the means of sensorial participation with all things. Abram suggests that "the recuperation of the incarnate, sensorial dimension of experience brings with it a recuperation of the living landscape in which we are corporeally embedded" (65). By this means, we as a species can regain our place in the natural world. When we accept these concepts with humility, we come to realise "that our inner human nature can be understood in relation to external nature", which is Gifford's third fundamental for post-pastoral literature (156). In poems as early as "Metamorphoses" for example, the biological detail of the human anatomy grounds the human in the flesh of the world. Longley's personae are not merely observers of the natural world but are partakers in it:

\author{
A boulder locked in a cranny, \\ A head without a face, she waits \\ For rain to hollow out a font \\ And fill her eye in, blink by blink. (CP 140)
}

The human and the other-than-human are as if metamorphosed. The elements are more than emblems and more than background; they provide a tapestry of knowledge through which the language of the human body communicates. This could be likened to what Abram expresses under his title "The Body's Silent Conversation with Things" (49). This is at the most immediate level of sensory perception where the body's unpredictable impulses adjust to the 
ever-changing engagements of the surrounding terrain: "this silent or wordless dance always already going on - this improvised duet between my animal body and the fluid, breathing landscape that it inhabits", Abram says (53).

Human feelings and emotions are part of our being; connecting with the world outside of the self is what we crave. It is in the embodied experience that self, flesh and earth are deeply immersed in each other: a sense of fusion created to articulate the notion of interconnectedness, and the recognition of our own natural state. There is delicate interpretation of the connections between human doings, poetic commitment, and the essential laws nurturing both human and nonhuman nature in poems such as "Couplet" in Ghost Orchid, for example: the narrator says, "When I was young I wrote that flowers are very slow flames / And you uncovered your breasts often among my images" (CP 217). The romantic notions behind the metaphoric language of this poem amount to a humble openness to nature's revelation, not just of the physical world but of the physical act of human intimacy. The physical and the psychological permeate in a way that seems almost to suggest human ego vanishes in the moment of passion. In ecocentric terms, the poet has as if dissolved the boundary between human and environment. Not only does Longley project his personae beyond the periphery of the self into the environment but they appear to become part of the flesh of the world. Actual knowledge and analytic expectations about a phenomenon are set aside so that feelings and emotions can be apprehended subjectively.

Longley uses the language of silence as a response to chauvinistic anthropocentric reasoning. He is arguing for a philosophy based on both human and non-human interactive experience in poems such as "The Comber" in The Weather in Japan (CP 243). The nonhuman animal is essentially unknowable, but its meaning or intention can be imagined because we share common traits. The inclinations towards fight or flight, or to wariness or tolerance, for instance, are common to us and other animals. Through perception, a certain degree of communication can be established. Christopher Manes suggests there is a need to "re-establish communication with nature, not out of some nostalgia for an animistic past, but because the human subject that pervades institutional knowledge since the Renaissance already embodies a relationship with nature that precludes a speaking world" (25). For Manes, attending to ecological knowledge means metaphorically relearning its language.

The reciprocal participation between the experiencing body and the earth, known as perception, seeks to reinstate the kind of awareness of the natural world that precedes scientific knowledge. In Maurice Merleau-Ponty's terms, "The experience of phenomena ... is the making explicit or the bringing to light of the pre-scientific life of consciousness that alone gives the operations of science their full sense and to which these operations always refer" (Phenomenology 59). Merleau-Ponty's "operative language", which is the language of life and of action, of literature, poetry, and conversation (as opposed to "constituted language", which applies to science), is "called forth by the voices of silence, and continues an effort of articulation which is the Being of every being" (Visible 118, 126-7). An important consideration for post-pastoral literature is the direct sensuous apprehension of our natural being; along with all lifeforms we participate in a "dynamic blend of receptivity and creativity" (Abram 50).

The language of sensory perception and phenomenology, which is associated with silence, is employed by Longley to find expression in "The Comber", for example. Sensorial and phenomenological interaction reveals certain aspects of the otter's meaning:

A moment before the comber turns into

A breaker - sea-spray, raggedy rainbows -

Water and sunlight contain all the colours

And suspend between Inishbofin and me 
The otter, and thus we meet, without my scent

In her nostrils, the uproar of my presence,

My unforgivable shadow on the sand -

Even if this is the only sound I make. (CP 243)

The sense of human enmeshment in the world for Longley is not compromised by the distance he maintains between the human and other-than-human occupants of a given place. In this poem, sensory perception reveals that both are possibly long-term observers of the other. A reciprocated, healthy respect for the existence of the other is evident. Politics is suggested (albeit surreptitiously) in the word "unforgivable", but this word also communicates an exchange of feelings. The perceived "atmosphere" is strained between the narrator and the otter. The otter communicates displeasure in human company. The human, aware of ecological vulnerability, registers as an unwelcome intruder into the otter's immediate space. An intimate encounter with the other-than-human might well help us to think of physical existence in a more profound way. The communication of the state-offeeling between the narrator and the otter discloses a sense of connectedness through bodily presence and participation. The type of communication derived from sensation and perception comes from what Snyder calls "our inner wilderness areas", which he suggests are found in the depths of our mind, the unconscious (17). The human is an intricate part of the natural world. The psychological process of sensitively identifying with others cultivates a broader sense of identifying self with the natural environment. Longley recognises the fact that, in the words of Robyn Eckersley, "one's own individual or personal fate is intimately bound up with the fate of others" (62). The broader ecological self addresses the egocentric self.

Longley shows rather than tells how he feels in his perception of the natural world. Refering to Friedrich Schiller's essay “On Naïve and Sentimental Poetry”, Jonathan Bate says that self-consciously stating that we have feelings about the environment is a symptom "of the loss of integration with nature" (73); a deliberate admission of "feeling about" the subject enframes it. Longley's poetry is not utterly available for what Heidegger calls Ge-stell"enframing" ("The Question" 227). Longley recognises nature as a communal unit, changing incrementally and perpetually; in this sense it is not a fixed frame of reference for rhetorical debate. As expressed by Abram: "The body's actions and engagements are never wholly determinate, since they must ceaselessly adjust themselves to a world and a terrain that is itself continually shifting" (49). The sensing body is informed by the perception of a vigorous composite of receptiveness and resourcefulness by which every sentient being necessarily adapts to the world. Neither does Longley enframe the environment with the term "landscape", nor does he describe what he sees as being "picturesque" since terms such as these imply judgement which is generated by anthropocentrism.

Gifford's fourth fundamental for post-pastoral is the "awareness of both nature as culture and of culture as nature" (162). The poem "According to Pythagoras" (CP 202), for example, focuses on nature as culture in that the environmental microcosms are selfgoverning and operating independently. Poems as early as "Botany" in The Echo Gate, also present nature as culture in that nature is living, creating and fluctuating in its own eternal designs in a post-pastoral sense:

Afloat on their own reflection, these leaves

With roots that reach only part of the way,

Will fall asleep at the end of summer,

Draw in their skirts and sink to the bottom. (CP 129)

An example of culture as nature is found in the poem "Bird-Watching" (Angel Hill 56), where the poet indicates his desire to scatter his ashes; the physical remains after the cultural 
initiative of cremation are to be relinquished to the natural elements. In this image the "ebbs and flows of culture are natural flux in the post-pastoral sense" (Gifford 162).

In Longley's poems, the tangible living person is biological as well as historical. Sensation and emotion are expressed in the physical detail of the poem "Rune" in Poems, for example:

Poems in the palm of the hand, life-lines,

Fingers tapping the ridge of the shin-bone,

The bridge of the nose, fingerprints, breath. (CP 162)

The organic detail of the human anatomy grounds the human in the flesh of the world. As Terence Brown points out: "The distinctly cerebral quality of Longley's early work (in which the word 'mind' recurs) gives way as the poet matures to poetry marked by bodily awareness" (145). Each experienced landscape of Longley's life "is not a wandering troop of sensations or a system of ephemeral judgements but a segment of the durable flesh of the world" as Merleau-Ponty would have it (Visible 123). Each organism is there in its full ecological participation with the world rather than as a romanticised notion. The refusal to use a gilded concept, such as is the case with romanticism which is common to pastoral ideology, adds a sense of truth to his work.

\section{The Impact of Ireland's Social and Political Turmoil}

Longley wrote during the decades of social turmoil in both the Republic and Northern Ireland: 1970s, 1980s and 1990s. The regional "war", known as "The Troubles", which began in Northern Ireland in 1969 and ended with the Good Friday agreement of 1998, first appeared in Longley's second collection, An Exploded View. Russell concludes that: "The contents of An Exploded View suggest that instead of drawing on the explosive issue of the Troubles, Longley was trying to explode notions of a Northern Irish poetry based solely on reaction to the violence in the province" (98). Fran Brearton suggests that "The 'exploded view' is the ability to see both surface and depth - and with an eye for detail. In that sense, it does not so much signify something in ruins, or a vision shattered, as something seen - and therefore understood - more completely than ever before" (Reading 65). Longley's consciousness responded to the ever-changing nature of experience by reimagining and reinventing poetry's response to the social crisis; he offered a way for Ireland to move forward. His poems in that volume and those of Heaney written at around the same time, Wintering Out and Stations, imply that for both poets everyday life which continued on elsewhere was equally important to acknowledge as were the sectarian problems.

Longley's referencing biological interrelatedness furtively highlights the option for all parties to try to find ways of traversing social, cultural and political boundaries - an avenue that opens up new possibilities for peace. In "According to Pythagoras", for example, the narrator presents an image of productiveness, progress and harmony emerging from spoils: "bury your prize bull/ . . . and from the putrid guts/ Swarm flower-crazy bees, industrious country-types/ Working hard, as did their host, with harvest in mind". In his interview by Randolph, Longley said: "In my Mayo poems I am not trying to escape from political violence. I want the light from Carrigskeewaun to irradiate the northern darkness" (305). He is conscious of the need to address the issues. His work complies with the fifth post-pastoral element for literature as suggested by Gifford: "with consciousness comes conscience" (163).

By way of contrast, Heaney responds to the political and social crisis by centralising place, landscape and nature in his poetry. The essential element in his poetry is his homeland. As expressed by Sidney Burris, for example, "Irish place-names in the United Kingdom 
become for Heaney subversive incantations that both glorify his Celtic lineage and establish its integrity in British Northern Ireland" (12), such as is found in the poem "Anahorish" (OG 46). Heaney's pastoral poetry appears to highlight the perceived value of the status quo ante: living at a time when society was supposedly not challenged by social and political unrest. "Anahorish" establishes a connection between him and the "mound dwellers" of his distant Irish bloodlines, people who are imagined to be dwelling in peace. In "Place and Displacement" Heaney points out what he considers to be an example that resembles the situation of the poet in modern Northern Ireland, and he hints at his development of a new level of consciousness when he refers to the dilemma Wordsworth faced with the outbreak of the French Revolution: conflict between the sensibilities of the poet, his love of England, and political crisis (112). Heaney's poetry is an expression of love for his country, and his perspective certainly offers a vision of security and stability that is vital at a time of civil unrest, but for the purpose of my argument, the explicit and implicit references to land ownership in a pastoral sense throughout his oeuvre contrast starkly with Longley's postpastoral vision. In poems such as "The Other Side" (OG 59-61) from Wintering Out, for instance, Heaney's narrator mentions "our fallow", "our bank", "our scraggy acres", "our small lanes"; the outcomes for land and other lifeforms are shaped and governed by humans. On the contrary, Longley's Mayo poetry in particular does not regionalise land and "there is little sense of ownership or belonging", as noted by Tom Herron (83).

When discussing the sixth quality for post-pastoral literature, Gifford suggests that "The desire to heal our relationship with the earth we inhabit must accompany the healing of our relationship with ourselves as a species" (165). Longley's poetry bears witness to social discord that has its genesis in the same hubristic tendencies that spawn environmental exploitation. He is conscious of the ecological crisis and its effects on the natural world (and on humans since they are part of the biosphere); the devastating results of conflict, and of Western societies' unrestrained industrialisation. The combination of social, historical and environmental consciousness in his poetry generates a strong ecocentric focus for his aesthetics concerning relationships including that between humans. As Eckersley suggests:

The ecological model of internal relatedness upon which ecocentrism rests applies not only in respect of human-nonhuman relations but also in respect of relations among humans: in a biological, psychological, and social sense we are all constituted by our interrelationships between other humans, and our political, economic, and cultural institutions. (53)

Longley's poetry presents the inter-human violence of war as offensive to the nature of things. This could also be seen as what Eckersley determines is a "positive affirmation [her emphasis] of the fact of our embeddedness in ecological relationships" (53). In his poetry, happenings reverberate across the human and ecological community because everything is inextricably tied up with everything else. Thus, a parallel is drawn by Longley between his poetic response to social turmoil and ecological imperatives. And his work encourages mutual tolerance and respect in the broader political struggle through what Russell terms "his articulation of an aesthetic and spiritual theory of reconciliation" (92). See Richard Kirkland's Literature and Culture in Northern Ireland for a comprehensive analysis of the work done by Michael Longley who became the first Literature Officer at the Arts Council of Northern Ireland (53-84) and of Edna Longley (85-120) - each promoting Northern Irish literature and reconciliation.

In Longley's poem "Remembrance Day" in No Continuing City and later called "Aftermath", in $C P$ (31), the peaceable presence of the birds existing amid the catastrophic and the ominous draws attention to the paradoxical contrast between unnatural and natural 
existence and death by conflict. The birds unceremoniously and unremittingly go about their usual habits but in this case their choice of location, which is closely linked to the human domestic space of meadows and gables, has solemn implications:

\author{
Imagine among these meadows \\ Where soldiers sink to dust \\ An aftermath with swallows \\ Lifting blood on their breasts \\ Up to the homely gables, and like \\ A dark cross overhead the hawk. (No Continuing City 44)
}

A parallel is drawn between the threat that humans cause to other humans and that which the birds cause to others of their kind - in this case, the hawk is threatening the swallows. The moral question could also be raised concerning what appears to be natural for the birds (in that they kill their kind as a means of survival) has emotionally disturbing ramifications for humans. From a post-pastoral perspective, this poet does not romanticise nature or human relationship to it. This poem could be interpreted as meaning that both the human and the nonhuman are subject to threat in one form or another. Species other than humans might also be conscious of threats to their existence. Whichever way this poem is interpreted, the birds appear to carry the emotional weight of unnatural human death.

Despite his concern for the escalating ecological crisis, however, Longley shows little interest in blatantly politicising the natural environment or the human response to it. Mostly he prefers to advance his political argument through indirect environmental poetics that are based on experiential insight. A political view is evident in poems such as "Lapwing" in The Weather in Japan, however, but is referred to obliquely:

For the poisoned swan unfolding on David's pond

Like a paper flower in a saucer. "Milkwort",

I mumble to the piss-scattering wind. "Why me?"

The lapwing replies and falters like a bi-plane

Above the nest. "Why me?" (CP 243)

The economical use of politically charged words has a surprising impact when situated amidst language that otherwise encourages belief in the possibility of harmonious relationships. The reader might also be prompted to ponder over the complex junctions and incongruities between ecopoetics and ecopolitics not least of all because their purposes and their approaches are different (Bate 42). Ecopolitics is instrumental whereas ecopoetry is experiential.

A sense of nature as a complex interactive system in Longley's poetry suggests that the exercising of man's vulgar powers and the ensuing chaos is an unwarranted affront to natural order. In his address to a deceased poet in "In Memory of Charles Donnelly" in Gorse Fires he says:

Minutes before a bullet hits you in the forehead

There is a lull in the machine-gun fire, time to pick

From the dust a bunch of olives, time to squeeze them,

To understand the groans and screams and big abstractions

By saying quietly: "Even the olives are bleeding". (CP 191) 
In this poem, the catastrophic and the mundane exist side by side. A parallel is drawn between the human and the non-human in physical existence and participation. The qualities of being human are no more special than those of the non-human, just different.

The juxtaposition of the peaceable elements and the catastrophic in much of his poetics also seeks to locate man in a natural order that is itself both violent and peaceable. He considers brutality from not only cultural and historical perspectives but also from an environmental one. For instance, the "something" that had "followed the / Fox and the crow", which was "desperate for / a last morsel and was / Other than wind and rain", in the poem "Casualty" in An Exploded View (CP 51), I suggest is the earth itself. Brutal reality in environmental terms is not exaggerated; all species consume other species and the earth eventually consumes all.

When addressing Heaney in his poem "Letters" in An Exploded View (1973), Longley speaks of "the sick countries" they call home as a place "Of broken bones and lost scruples", but his conscience is always divided between the Troubles and the natural world:

So let it be the lapwing's cry

That lodges in the throat as I

Raise its alarum from the mud,

Seeking for your sake to conclude

Ulster Poet our Union Title

And prolong this sad recital

By leaving careful footprints round

A wind-encircled burial mound. (CP 60-61)

Just as is the case with all life forms, both the human and the nonhuman will eventually be taken into the mud of which this poem refers. The emotional weight that is central to Longley's poems on warfare and violence is not just with a "tone of compassionate anger" as Brown suggests (143), but also understandable resignation; humanity has not yet learnt that war not only threatens "the enemy", but also the allies, and other life forms and habitats.

In "Room to Rhyme", Longley reflects on a lifetime of friendship that flourished between himself, a protestant, and the catholic Heaney, despite decades of sectarian conflict in Ireland:

We drove after Bloody Sunday to join

The Newry March - road blocks, diversions -

Time enough to decide, if we were asked

At gunpoint: And what religion are you? (Angel Hill 48-49)

In a broader political context religion might matter, but on a personal level for the poet religion is not a priority that should divide humanity. The environmental focus throughout Longley's entire oeuvre provides a way of contextualising sectarian differences; we are reminded of environmental responsibility for the survival of the human species, regardless of religion. Longley's poetry opens up the possibilities for people to envisage both human and biota existing in harmony. The negative elements of human-to-human interaction and the positive elements of human experience with the natural world in his work might not only have a positive influence on attitudes towards the environment, but also on social, cultural and political outcomes.

At times the poet seems to have felt helplessly inadequate and wondered at the purpose of poetry in such a political climate. Kirkland, in Literature and Culture in Northern Ireland, quoted a poignant passage from Longley's introduction to Causeway: The Arts in 
Ulster: "confronted with tragedy in his own community, as he has been in Ulster, the artist might be inclined to question the validity or at least the usefulness of his vocation (M. Longley 1971:9)", (57). In Longley's poem "An Exploded View”, he addresses fellow Northern Irish poets Derek Mahon, Seamus Heaney and James Simmons with political concerns about the role of poetry. He says:

We are trying to make ourselves heard

Like the lover who mouths obscenities

In his passion, like the condemned man

Who makes a last-minute confession,

Like the child who cries out in the dark. (CP 39)

In this poem man seems unstable and at his most vulnerable. There is also a levelling effect between the lover, the condemned man and the child; each is at the mercy of something beyond their control. In Poetry and Posterity, Edna Longley uses Michael Longley's poem "Landscape" in Man Lying on a Wall (CP 91) to explain what she terms a renewal of "dialectic between art and instability, which includes a destabilised self", that she notices in recent Western poetry (124). She says this poem 'cuts 'imagination' down to the diffuse materials on which it works ('Here my imagination/ Tangles through a turf-stack/ Like skeins of sheep's wool'), and subjects 'thought' and the poem itself to the natural world's centrifugal dynamics" (Poetry and Posterity 124). This strategy to merge the poet's images into the natural world, which communicates perceptual disorientation, questions not only the possibility of a stable human presence, but also the perceived human advantage over the natural world.

The narrator seems disoriented and hesitant in the cryptic poem "Points of the Compass" in Man Lying on a Wall, who begins his journey at a "confluence of lines, I Crossroads and roundabout" (CP 94-95). In "Poetry of the 1960s" Brearton suggests Longley's early poems "do not lead the reader on a well signposted route to a comprehensible sense of 'identity', 'home', or 'religion"” ("Poetry of the 1960s" 107), yet one might expect this is required of poetry to restructure increasingly tumultuous political, social and ecological influences. In Reading Michael Longley, Brearton acknowledges, however, that: “Longley's domestic space, his understanding of 'home', and his pastoral 'elsewhere', or home from home, are never remote from either the mundanities or the brutalities of everyday life in Northern Ireland in the 1970s" (145). Even as the social turmoil has subsided in Ireland, so the threat to the environment has increased globally. The increasing threat to survival of all life's systems calls for equally dynamic poetry.

This poet, who may have felt powerless amid the man-made chaos in earlier decades, with age has become tenacious, confident and decisive. His poetry accommodates new insights. In his address to the poet Anne Stevenson in "Old Poets" in Snow Water, he says:

Old Poets regurgitate

Pellets of chewed-up paper

Packed with shrew tails, frog bones,

Beetle wings, wisdom. (CP 302)

This poem brings forth the depleted remains of once-living things and places them alongside an active kind of learning born of experience, learning that he continues to apply to environmental concerns.

\section{Conclusion}


Not only is Longley's poetry a counter to the "long shadows" of Irish history but it is a stand against the excesses of modernity. His imaginings of the interactions between humans and alternative life forms, as well as between humans, might have been socially and politically beneficial given the failure on both sides of the sectarian divide to find a peaceful solution for the social turmoil and paramilitary violence in Northern Ireland that ran parallel to his career.

The biological detail in his poems forms a secure foundation upon which ecocentric values and post-pastoral poetry can flourish. The natural world is not hidden behind idyllic, sentimental or nostalgic Arcadian notions of accommodating human wants or needs. Longley does not romanticise or sentimentalise nature or rural life. Nature for him is extraordinary in its full ecological participation in the world. His poetry pushes the boundaries beyond the parameters of the traditional pastoral by embracing ecocentric values. It provides an infinite supply of images for the expression of human thoughts, feelings, and interactions. This poet is guiding the reader to an emotional space by employing the concepts of sensory perception and phenomenology to provide new environmental aesthetics of an integrated world that includes the human.

\section{Works Cited}

Abram, David. The Spell of the Sensuous. New York: Vintage Books, 1997 (1996).

Alpers, Paul. What Is Pastoral?, Chicago: University of Chicago Press, 2011. 1 May 2017. http://ebookcentral.proquest.com/lib/newcastle/detail.action?docID=672982.

Bachelard, Gaston. On Poetic Imagination and Reverie. Trans. Colette Gaudin. Dallas: Spring Pub., 1998 (1987).

Bate, Jonathan. The Song of the Earth. London: Picador, 2001 (2000).

Brearton, Fran. "Poetry of the 1960s: The "Northern Ireland Renaissance". The Cambridge Companion to Contemporary Irish Poetry. Ed. Matthew Campbell. Cambridge: Cambridge U.P., 2006. 94-112. 5 December 2017.

https://doi-org.ezproxy.newcastle.edu.au/10.1017/CCOL0521813018.006

_. Reading Michael Longley. Tarset, Northumberland: Bloodaxe, 2006.

Brown, Terence. "Mahon and Longley: Place and Placelessness". The Cambridge Companion to Contemporary Irish Poetry. Ed. Matthew Campbell. Cambridge: Cambridge U.P., 2006. 133-48. 4 December 2017.

https://doi-org.ezproxy.newcastle.edu.au/10.1017/CCOL0521813018.

Buell, Lawrence. The Environmental Imagination: Thoreau, Nature Writing, and the Formation of American Culture. Cambridge: Harvard U.P., 1995.

Burris, Sidney. The Poetry of Resistance: Seamus Heaney and the Pastoral Tradition. Athens: Ohio U.P., 1990.

Coupe, Laurence, ed. "General Introduction". The Green Studies Reader: From Romanticism to Ecocriticism. London: Routledge, 2010 (2000). 1-8.

Delattre, Elisabeth. "Michael Longley's Poetry of the Elements in Snow Water". Estudios Irlandeses 6 (2011): 1-7. 18 November 2017. https://www.estudiosirlandeses.org/

- "The Great War and All That in A Hundred Doors by Michael Longley". Estudios Irlandeses 10 (2015): 77-84. 18 November 2017. https://www.estudiosirlandeses.org/

Eckersley, Robyn. Environmentalism and Political Theory: Toward an Ecocentric Approach. Albany: State University of New York Press, 1992.

Gifford, Terry. Pastoral. London: Routledge, 1999.

Heaney, Seamus. Preoccupations: Selected Prose 1968-1978. New York: Farrar Straus Giroux, 1980. 
Opened Ground: Poems 1966-1996. London: Faber and Faber, 1998.

"Place and Displacement: Recent Poetry from Northern Ireland". Finders Keepers: Selected Prose 1971-2001. London: Faber and Faber, 2003 (2002).

Heidegger, Martin. "The Question Concerning Techology". Martin Heidegger: Basic Writings from Being and Time (1927) to The Task of Thinking (1964). Ed. David Farrell Krell. London: Routledge, 2011 (1978). 217-38.

Herron, Tom. "Mayo Littoral: Michael Longley's Eco-elegies". New Hibernia Review 14. 4 (2010): 74-89. 5 December 2017. muse.jhu.edu/article/412024.

Kennedy-Andrews, Elmer. "Conflict, Violence and the "Fundamental Interrelatedness of All Things' in the Poetry of Michael Longley". The Poetry of Michael Longley. Ed. Alan J. Peacock and Kathleen Devine. Gerrards Cross, UK: Colin Smythe, 2000. 73-99.

Kerrigan, John. "Earth Writing: Seamus Heaney and Ciaran Carson." Essays in Criticism: A Quarterly Journal of Literary Criticism 48.2 (April 1998): 144-168. 10 November 2017. http://search.ebscohost.com/login.aspx?direct=true\&db=mzh\&AN=1999053337\&login.asp\& site=ebhost-live\&scope $=$ site.

Kirkland, Richard. Literature and Culture in Northern Ireland Since 1965: Moments of Danger. London: Longman, 1996.

Longley, Edna. Poetry \& Posterity. Tarset, Northumberland: Bloodaxe, 2000.

Longley, Michael. No Continuing City. Bristol: Defour, 1969.

—. "Strife and the Ulster Poet". Hibernia 33.21 (November 1969):11.

- ed. Causeway: The Arts in Ulster. Belfast: Arts Council of Northern Ireland, 1971.

Collected Poems. London: Cape Poetry, 2006.

- A Hundred Doors. London: Cape Poetry, 2011.

- Angel Hill. London: Cape Poetry, 2017.

Manes, Christopher. "Nature and Silence". The Ecocriticism Reader: Landmarks in Literary Ecology. Ed. Cheryll Glotfelty and Harold Fromm. Athens, Georgia: University of Georgia Press, 1996. 15-29.

Meeker, Joseph M. "The Comic Mode". The Ecocriticism Reader: Landmarks in Literary Ecology. Ed. Cheryll Glotfelty and Harold Fromm. Athens, Georgia: University of Georgia Press, 1996. 155-69.

Merleau-Ponty, Maurice. Phenomenology of Perception. Trans. Donald A. Landes. London: Routledge, 2012.

- The Visible and the Invisible. Trans. Alphonso Lingis. Ed. Claude Lefort. Evanston, IL: Northwestern U.P., 1968 (1964).

Oelschlaeger, Max. The Idea of Wilderness: From Prehistory to the Age of Ecology. New Haven: Yale U.P., 1991.

Peacock, Alan J. and Kathleen Devine. "Introduction". The Poetry of Michael Longley. Gerrards Cross: Colin Smythe, 2000. i-xxi.

Potts, Donna L., ed. Contemporary Irish Poetry and the Pastoral Tradition. Columbia: Missouri U.P., 2014. 14 May 2017.

http://ebookcentral.proquest.com/lib/newcastle/detail.action?docID=3440764

Randolph, Jody A. "Interview: Michael Longley and Jody Allen Randolph". Colby Quarterly 39.3 (2003): 294-308. 4 December 2017. http://digitalcommons.colby.edu/cq/vol39/iss3/12.

Russell, Richard Rankin. Poetry and Peace: Michael Longley, Seamus Heaney, and Northern Ireland. Notre Dame, Indiana: University of Notre Dame Press, 2010.

Snyder, Gary. The Practice of the Wild. Berkeley, CA: Counterpoint, 1990.

Received: 12 June 2017 Revised version accepted: 11 December 2017 
Cassandra O'Loughlin completed a $\mathrm{PhD}$ in the Discipline of English at the University of Newcastle, Australia, where she is currently a Conjoint Fellow in the School of Humanities and Social Science. The focus of her doctoral thesis is Ecocritical Theory and Ecopoetics. Her work appears in various anthologies, and in journals such as The Australasian Journal of Ecocriticism and Cultural Ecology, Antipodes (USA), Plumwood Mountain, Southerly, Meanjin, Overland, Mascara Literary Review and Earthlines (UK). A volume of her ecopoetry, Taking My Breath: Ecopoems, was published by Ginninderra Press in February 2018.

cassandra.oloughlin@newcastle.edu.au 